\title{
Of Prostitutes and Parchments: Sex, Immigration, and a Poetics of Skin in Lourdes Ortiz's Fátima de los naufragios
}

La preocupación cultural por la inmigración y sus consecuencias para la identidad española en las últimas décadas han proliferado en textos literarios que convierten la superficie del cuerpo inmigrante, y en particular el cuerpo inmigrante femenino, en un pergamino para la re-inscripción del discurso español y patriarcal. La colección Fátima de los naufragios (1998) de Lourdes Ortiz cuenta con dos relatos que se enfocan en el cuerpo femenino marginado por intersecciones de raza, nacionalidad, clase y género. A la mujer inmigrante se la ve como virgen/puta, objetivo de los deseos y las ansiedades de los personajes españoles. Al explorar la perspectiva dominante de los españoles, Ortiz critica el sometimiento sexual y cultural inscrito problemáticamente en la membrana de la piel en general y del himen en particular. En lugar de eclipsar el cuerpo inmigrante, Lourdes Ortiz rastrea la superficie de la piel para destapar la política de la identidad española. Su ficción plantea una poética de la piel como un acercamiento táctil y ético a la representación cultural de la inmigración y la identidad en España.

Language is a skin: I rub my language against the other.

Roland Barthes, A Lover's Discourse

The cultural preoccupation with immigration and its implications for Spanish identity in recent decades has yielded a proliferation of literary texts that focus on immigration. Many of these works reveal a penchant for turning the surface of the immigrant body, and particularly the female immigrant body, into a parchment for re-inscribing both Spanish and patriarchal discourse. ${ }^{\mathrm{I}}$ Lourdes Ortiz's 1998 short fiction collection Fátima de los naufragios features two stories that focalize a female body marginalized at the intersection of race, nationality, class, and gender. The female African immigrant is rendered in the first tale, "Fátima de los naufragios," as a black Madonna and in the second story, "La piel de Marcelinda," as a prostitute. In both texts the local Spaniards first view the 
immigrant woman as alien and then incorporate her into their vision of identity to reify their perception of themselves as the center. These narratives have elicited diverse critical reactions, ranging from the vision of a new, hybrid national identity for Spain interpreted by Rosalía CornejoParriego ("Espacios híbridos"), to stumbling into "la falacia intencional" and privileging the Spanish perspective in the view of Jorge González del Pozo (96), to the possibility of "mutual acceptance and appreciation" read by María DiFrancesco (212), to the condemnation of Spain's xenophobic, exclusionary identity politics seen by critics such as Maryanne Leone, Gema Pérez-Sánchez, and Tabea Alexa Linhard. I position myself on the latter end of the spectrum in my focus on how the stories critically represent skin as a marker of identity and difference.

In these two juxtaposed tales, Ortiz critiques the sexual and cultural subjugation problematically imbued in the membrane image of the skin in general and the hymen in particular, where the dark-skinned immigrant woman is figured as a virgin/whore who is a projection of the desires and anxieties of Spaniards. Throughout the two texts, narrative strategies serve to interrogate attitudes towards immigrants and undermine the notion of a singular, cohesive Spanish subject. The danger, however, is that these fictions, written by a white, autochthonous Spaniard, would in turn only objectify the black immigrant and further subsume her within a traditional, monolithic model of Spanish identity. However, rather than objectifying dark skin as a means of eclipsing the immigrant body, Lourdes Ortiz probes the surface of the skin to unsheathe identity politics in Spain. Her fiction proffers a poetics of skin as a tactile, ethical approach to the cultural representation of immigration and its influence on the construction of identity.

Skin is commonly conceived as the superficial sur-face - what lies above the face, the outer layer of the "true" being. If the body is the whole, the reasoning goes, then skin is simply synecdoche, a partial approximation, a shell that encases the true identity and that, sometimes, can be shed or taken on - you can put yourself in someone else's skin, for instance, in Spanish. ${ }^{2}$ This notion of transferability extends to the association of skin with money, a means of exchange. Yet the imagery of the cutis surpasses superficiality and detachment, as critics such as Claudia Benthien have asserted, for it is also "the symbolic surface between the self and the world" (I). Benthien discusses the misleading discourse of what she terms "the semantics of skin":

To be sure, our awareness of the unknowability of the other, of the potential divergence between the inner and the other, between reality and appearance, has 
had little impact (so far) on the semantics of the skin: we still believe that something is true if it is naked, the absence of makeup is still seen as a mode of authenticity, and nakedness is still the ideal of the natural. 'Only skin deep' connotes superficiality, and only that which gets under one's skin can truly touch or arouse a person. But the interplay of the visible and the invisible, of surface and depth, reveals itself by no means as natural. Rather, it is a relationship subject to a great many strategies of interpretation and staging. Nakedness is therefore not an ontological category but rather a relationship that always relates to something else. (ix)

The skin, then, is a matter - arguably the most noticeable matter - of subjectivity. As both a boundary and a contact zone, this surface is a site of inter-face - the membrane that mediates between two identities in the frictional divide between contiguity/continuity.

Perhaps the membrane of skin that most embodies the compounded subjugation of the dark-skinned female immigrant in Spain is the hymen. In Dissemination Jacques Derrida figures the hymen as the dividing membrane between self and other, a tissue that is and is not penetrable, that is both the obstacle and the entryway to sexual union, and that is - for women - the emblem of intact sexual and even property status (212-213). This membrane is malleable, a penetrable image of identity/alterity. It is imprinted with historical and contemporary cultural trappings that can invest or di-vest the skin with power in the negotiation of identity. If the membrane of skin is the embodiment of corporeal and cultural contact, then the tissue of the hymen is the quintessence invested with purity, pleasure, and price. It is the parchment where multiple marginal identities intersect most volatilely in the cultural inscription of power. ${ }^{3}$ Lourdes Ortiz's fiction probes the skin to explore the ruptures, cuts, and folds of contradiction in the ways in which the female immigrant body is flayed as a parchment for the inscription of Spanish identity.

Ortiz's first tale, "Fátima de los naufragios," centers on a Moroccan woman, one of numerous would-be immigrants on a boat that disastrously capsized. Thereafter she remains on the beach for years, staring at the sea and grieving for her lost husband and child, whilst the Spanish villagers come to revere her as "la Virgen de las pateras, nuestra señora de los naufragios" (22). As Maryanne Leone has observed, the body of the African woman in Ortiz's third-person narration is rendered as an object focalized by the Spanish villagers, and the dynamics of focalization in both stories "illustrate the processes by which a homogenizing ethnic perspective erases and distorts some categories of difference and, concurrently, edifies ethnic frontiers" (452). The oral tone of the narrative discourse positions 
readers as Spaniards, as though they were a unified subject; the story refers to villagers' gossip about the African woman as if the Spaniards were people we already knew, whereas it fully explains the background of the few immigrant characters whose opinions it recounts, such as the boy Mohammed who also survived the capsized boat. This technique situates readers firmly on the Spain side of the divide between the familiar and the foreign, implicit and potentially complicit participants in the objectification of the immigrant other and the romantic idealization of a homogenous Spanish nation. ${ }^{4}$

The Spanish villagers (and readers) watch the African woman, name her, and struggle to explain her. The narrator reports, "Fátima de los naufragios la llamaban. Se pasaba las horas junto a la orilla oyendo los sonidos del mar. Unos decían que era vieja y otros joven, pero era imposible percibir la edad tras aquel rostro convertido en máscara que guardaba señales de lágrimas, surcos ovalados bajo las cuencas de los ojos" (7). The locals ponder her yet are baffled at how to interprete her, for they perceive her face, furrowed by tears, as a mask that conceals the unknown. While her skin is marked by sorrow, her body is characterized by silence and stasis: 'La muda, la llamaban los niños y los 'maderos' pasaban a su lado sin pedirle papeles, como si, viéndola a ella, de pie, inmóvil sobre la playa, transformada en estatua de dolor, ellos pudieran pagar su culpa" (7). Their perception transmutes the African mask, a mysterious metonymy, to a more familiar totality that they feel they can comprehend and contain: a statue that imparts forgiveness. As Leone affirms, "in imagining this Muslim figure as Catholic, the Spanish locals make Fátima more familiar to them; in effect, they domesticate her Muslim otherness" (456). Rather than recognizing the immigrant body as a reminder of the economic and social inequities symbolized and played out on the maritime border of the sea between Spain and Africa, the locals view the woman as an icon that eases their sorrow from having lost so many of their menfolk to the sea. On a deeper level, their "acceptance" of her comes only through their incorporation of her presence into their worldview, to assuage their guilt at denying safe harbour to so many immigrant others.

While the first story explores the Spanish conversion of the African woman into a Virgin mother on the coastal border, the second tale, "La piel de Marcelinda," centers on a dark-skinned immigrant girl who is forced to work as a prostitute in a roadside brothel on the periphery of the city. As an immigrant from "Jamaica o algo así, un sitio exótico y caribeño" (26), this character adds further complexity to Ortiz's dialogue with Spain's history of colonization, slavery, and racial subjugation. Dark immigrant skin is not simply an issue directly between Spain and Africa, but one of 
globalized and historical exportation, exploitation, and multiple displacements. The narrative is focalized and recounted by a male Spanish guard, who views all the dark-skinned prostitutes as an amalgam of exotic otherness. Another of the Spanish guards in the brothel, Chano, feels affection for the girl and tries to limit her exposure to the cruelties of the trade: “Es una chavala, tú, una niña. No tendrá más de trece,' decía y se ponía en plan sentimental, de salvamundos: que pobrecilla, que fuera de su tierra, que a lo mejor la habían vendido sus padres o algo así, o que la habían engañao" (27). Chano hovers over her to the point of scaring most clients away from her, keeps careful watch to ensure that those who do use her do not stay too long, and warms her with coffee, cognac, and blankets when frigid temperatures make unbearable her nightly outdoor duty of displaying her bodily wares to lure in more men. The narrator regularly tries to restrain Chano from ruining the girl's career by scaring away the johns and angering Goyito, the pimp in charge.

The story culminates at the end of one nightshift, in the early hours of the morning, when four Spanish men arrive, notice Marcelinda, and demand to all use her together. She refuses. They grab her, so Chano attacks them, whereupon they knife him and then race off in their car. The girl falls on Chano, sobbing, and holds his body while he dies. Moving her hands all over him, she becomes drenched in his blood. She then finds the knife Chano had used in her defense, raises it, and thrusts it into her own belly, killing herself. The red blood that saturates the skin over her womb may symbolize cleansing, yet also contamination, of the contested site of sex/virginity. Notably, it is not only her blood, but also Spanish blood shellacked there. A witness to the disturbing death scene, the narrator describes how the dead girl's shiny black skin becomes more waxen and then dried up, an object of horror: “¡Había que verla!” (42).

As the events of the first story propose and the title of the second story proclaims, the skin of these women is the prominent screen on which the desires and fears of Spaniards are projected. Karmen MacKendrick theorizes how we conceive of the skin and the other as a philosophical awareness of grasping or subsuming the other into the self. Whereas preNietzschian philosophy reflected what MacKendrick calls a prehensile effort to grasp and totalize the other within the self, from Nietzsche onward philosophy is preoccupied with thematizing "that which is both fragmentation and joining, schism and suture ... a philosophy of the touch that does not grasp, the fold that does not close up, the cut that reveals the complexities of surface..." (7). The surface is thus a paradoxical, liminal marker of the inner/outer: "...dealing with surfaces we never do find the complete satisfaction of in-depth exploration; the surface is inexhaustible, 
the cuts and folds infinitely multipliable; there is always one more limit toward which word and flesh reach, at which they approach one another" (9). Touching, rather than grasping, then, draws near without possessing the other in corporeal and cultural contact. Derrida writes: "To touch is to touch a border, however deeply one may penetrate, and it is thus to touch by approaching indefinitely the inaccessible of whatever remains beyond the border, on the other side" ("Le toucher" I43). The indefinite approach of touch comes in contact with alterity without containing it.

In Ortiz's narrative exploration of the ways in which discourse inscribes identity on the body, her text underscores repetition and rupture as linguistic strategies that mime touching, rather than totalization, in an ethical treatment of the other. MacKendrick argues that ethical language seeks not to totalize the other through the metaphorical grasp, but rather "It touches - tracing out an often-broken path across a surface. It folds back upon itself to multiply the questions, unfolding new questions with every seeming answer. It cuts - it intersects, it fragments, it opens possibilities. It does not grasp" (7). She distinguishes repetition as a key tactile feature of such language: "[T]o understand tactilely is almost certainly to understand by repetition, to run our hands over or to feel our skin in contact. Not only moving, but moving back, going over, questioning and returning. Not only saying, but always saying it again" (54). Similar to touch, the fold is an image of repetition, but one that also evokes layered complexity. MacKendrick represents a further ethical strategy with the metaphor of the cut: "[W]e find the cut as ... the flip side of the fold. That is, as articulation links together, acknowledging a distance but never quite cutting apart, disruption breaks apart the articulate unfurling. It cuts in ... Surely we have all faced the phenomenon of an articulation so perfect and so self-contained as to leave no space for the conversational. The fissure is vital to communication..." (I42). Ortiz's tales evoke the repetition of discourse and imagery that touch the female African immigrant body time and again, in an always incomplete effort to capture it. At the same time, her narrative strategy subverts the Spanish characters' efforts to totalize the immigrant when it displays discursive strategies and imagery that complicate and cut into their unifying, subjugating view. The reiteration and rupture in her tales enacts a movement of approach, resistance, and retreat, over and over, that emphasizes the futility of the Spanish attempt to grasp the African subject, in the double sense of holding and comprehending.

The most overt discursive representation of repetition is the Spanish villagers' view of the African immigrant as virgen morena, a strategy by which the Spaniards strive to interpellate her within their Catholic, 
patriarchal paradigm..$^{5}$ Leone has observed insightfully of Fátima that, "[b]y converting her into not just a virgin, but the Virgin, the locals erect an impenetrable sexual border, her chastity, defusing the risk, so to speak, of ethnosexual border crossings" (457). Gema Pérez-Sánchez has argued that "Fátima de los naufragios" suggests there is no way for Spaniards to represent the Arabic other without falling into the primitivism of colonial discourse (563), particularly in light of the history of Spanish/Moroccan relations - a history that has been lucidly analyzed by critics such as PérezSánchez, Daniela Flesler, and Susan Martin-Márquez. I would add that the Spaniards in this tale see the grieving dark woman who is indifferent to them as a threat, which they try to ameliorate by idolizing her as the salvational virgin and incorporating her into their own familiar Catholic discourse. They make her the Virgin personified by repeating descriptive imagery like a litany: "Allí, quieta, expectante, con los ojos clavados en una distancia que ya no era de este mundo..." (8). Gossip, through the force of repetition, renders discourse as truth and creates belief: "Felisa, la panadera, oyó comentar a una de sus clientas que la mujer tenía ... dotes milagreras y que probablemente con su roce podía curar a los enfermos. Pero nadie se atrevía a acercarse y menos a palparla. La santa mora silenciosa miraba al mar y lo escuchaba..." (9-10). Upon learning what happened to the woman from Mohammed, the only other survivor of the shipwreck, the Spanish women of this fishing village sympathize, for they have lost many of their own to the sea: "Pasaba un ángel sobre el grupo y entonces todas comprendían a la mora y se ponían en su lugar y la mora era como una proyección de sus miedos y una especie de garantía de pacto con las aguas. Fantasma, aparición o santa o virgen morena, contagiaba su añoranza..." (I8). Through the repetition of their discourse the locals choose to identify with the African woman as a shipwreck survivor, but not as an immigrant. In rendering her as a larger-than-life projection of their own loss and grief, they dehumanize her and ignore what she lacks as an immigrant at the most basic level of day-to-day living. They imagine that she weeps for them, like their own Virgin but with a suntan: "Tiene la misma cara de la Macarena, una Macarena tostada por el sol" (7). As Leone has observed, the women "change Fátima's religious identity as they craft her into several Catholic icons: the Macarena, the Virgin of Carmen, and 'la moreneta' (IO), a reference to the Virgin of Montserrat..." (456). Like the Virgin of the Macarena, paraded through the streets of Seville during Holy Week, they believe the African woman weeps for the death of her son, representing and absorbing the grief of all.

In "La piel de Marcelinda" the discourse of virginity is repeated, but is now folded over to introduce layers of complication. By focusing on the 
"other" side of the virgin/whore dichotomy, the story underscores the essential role that the other side of the hymen - sex - plays in constituting the border of virginal identity. The initial comparison of the immigrant prostitute with the Virgin is one of displacement, duplication, and distortion of the Catholic icon, when the narrator likens her to the pop culture figure, Madonna: "ique daba gusto verla con aquellos pantaloncitos azul claro de licra bien ajustados y aquel corpiño en plan Madonna con las tetas al aire!" (28). In referencing the famed performer who plays upon the idea that sexual desire is inherent to and heightened by the prohibition incarnated in the inviolate figure of the Madonna, the story accentuates the notion of sexuality as a construction and performance. The pop image of Madonna further highlights, as DiFrancesco notes, "the objectification of women's bodies" (206) and, in Leone's words, their "commercial value" (460). It foregrounds the female body as both virginal construct and sexual commodity. The bodies of the immigrant women in the story are viewed as exotic merchandise: "un lote guay de negratas que quitaban el hipo; buen material que, colocado junto a la carretera, impresionaba, tío. Muslazos, caderas y esa piel negra suave y con un brillo de zapatos recién lustrados de charol de bailarín de claqué, juna pasada para la vista y para el tacto!" (25). They embody the figurative association of skin with money. As Chano fixates on his favorite, however, he rejects her sexuality in favour of the other extreme: "Y no es que el Chano se lo hubiera hecho con Marcelinda, que la trataba con un respeto como si fuera la virgen o la hermana" (36). The girl's skin suggests her transposition from common commodity to religious icon, after Chano dies protecting her from sexual onslaught and she kills herself: "...el sol ... comienza a salir y todo toma un color rosa, un rosa amarillo muy pálido, y una por una [las tías] se levantan y se acercan y dan un beso a la Marcelinda, ique te digo que estaba hermosa, medio

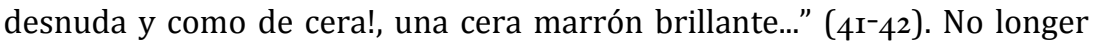
limited to the luster of black shoe polish, a lowly good, Marcelinda's skin is now elevated to the waxen status of virginal statue, illuminated by the sun and hallowed by the devout, her fellow prostitutes. The transformation from vulgar to virgin is finished on the skin.

In Ortiz's stories the projection of Virgin imagery on the immigrant is repeatedly symbolized when each protagonist is wrapped in a manta bestowed by Spaniards. This covering evokes the symbolism of the mantle worn by the Virgin Mary as well as fertility goddesses in art and literature. In The Virgin Goddess Stephen Benko discusses the influence of fertility goddesses on the imagery of the Book of Revelation's "woman clothed in the sun," a figure that is commonly rendered as the Virgin Mary in Christian art. Both Mary and non-Christian goddesses were often depicted 
as clothed in a robe - itself a symbol of the "cosmic tent" of the heavens over earth - emblazoned with celestial bodies such as the sun and the moon, designed to shroud "the great mystery that is called God" (Benko 98). ${ }^{6}$ In "La piel de Marcelinda" this association is overt, for the dead prostitute is effectively clothed in the sun when the sunrise bathes her black body in pink and yellow light as it seemingly transforms her skin into wax (4I). Even before the girl dies, however, Chano covers her with a blanket to protect her from the cold, in a passage cast in religious discourse: "...se acercaba a ella en plan misionero y le daba café caliente y coñac y le calentaba las manos con las suyas y le ponía la manta del coche sobre los hombros" (34). Missionary style, Chano strives to convert the girl from prostitute to Virgin by covering her body with the car robe, which literally conceals her sexuality and figuratively shrouds her body as, in Benko's terms, "the great mystery." The image of the manta is repeated in "Fátima de los naufragios" when the fishermen's wives identify with the African woman's loss of loved ones to the sea and give her a blanket to warm her during her vigil. For DiFrancesco, Fátima wrapping herself in the cloak "demonstrates a commitment to modesty, to the veil, and thus demonstrates her continued adherence to her faith" (203). Pérez-Sánchez proposes that Ortiz creates a "comunidad imaginada con las mujeres del Tercer Mundo" (564) with this show of solidarity.

Beyond these critics' interpretations, I would suggest that the recurrent image of the manta is layered with complication, since it can also be viewed as a superficial cover for the act of subsuming the immigrant's identity within that of the Spaniards in the tale. The manta enveloping the immigrant woman is not just a miming of touch, in MacKendrick's terms, but also an image of the fold, which involves repetition as well as layers, which evoke complexity: "Touch tends to repetitious patterning; folds tend to multiplicity and complication" (93). The Spaniards' bestowal of the vestment on the woman symbolically repeats the traditional ritual of investing authority in the religious statue through the robe, giving her what Benko calls "a second skin" (IOI). This second skin may also be seen as a symbolic hymen restoration, to impart Virgin status. The African Virgin's cloak, as an extension of the skin and the hymen, represents a new facet of identity, a Catholic conversion. Yet re-dressing the immigrant body does not redress the injustices wrought against it, nor does it alter the skin beneath.

Despite the repetition of the discourse of Spanish Catholicism through the imagery of the virgen morena, there is also rupture in its continuity, for that Virgin harbors reverberations of an alternative African identity that problematizes the imperial tendency to whitewash and contain the 
influence of African female power in Spain. The Catholic iconography of the black Virgin, reiterated throughout Europe and the Americas, gives rise to conflicting theories of her origins. Some say these statues are black due to age, atmospheric conditions, the cumulative effects of candle smoke, or efforts to create look-alike virgins that would lure dark-skinned natives to convert to Catholicism. While such factors may play a role in some cases, the vast preponderance of scholarship indicates that the figure of the Virgin Mary was a syncretic evolution of various fertility goddesses of the earth, especially the African goddess Isis, often represented as black, who "became a universal goddess who subsumed the functions of many other deities" (Redford 190). ' Lucia Birnbaum and other scholars trace black Madonnas in Spain to "prehistoric goddesses of Africa; e.g., to Caelistus who held power over the stars, the sun, moon, weather, and life, who melded with egyptian [sic] Isis and carthaginian [sic] Tanit. Caelistus also melded with anatolian [sic] Cybele, reminding us that Spain is a dramatic case of the complex layers of african [sic] migrations into Europe" (130). Birnbaum's research shows that the part of Europe formerly belonging to the Moorish empire is particularly populated with black Madonnas (206). The common function of black Madonnas, as Małgorzata OleszkiewiczPeralba notes, is "the protector, the consoler, the defender, the fighter for freedom and justice, and the great equalizer. Before her, gender, race, class, and ethnic origin are not debilitating distinctions but a foundation of strength" (II).

As Birnbaum notes and María DiFrancesco emphasizes in her important analysis of "La piel de Marcelinda," among the most influential of the precursors to the Virgin Mary is Isis, who was the most significant deity of the Mediterranean world during the millennium before the birth of Christ and the first half millennium afterward. Originating in Nubia, a region of upper Egypt, the influence of Isis spread to many points, including Greece and then the Graeco-roman empire, which carried her influence through Africa, Europe, and Asia (Birnbaum 20; Witt 69). Sister and wife of the male god Osiris, mother of Horus, Isis "became the queen of heaven and the mother goddess par excellence, the healer and the sorceress above all others" (Thury and Devinney 456). Sexuality was a fundamental part of the myth of Isis. When Osiris's brother, Seth, lured him into a box, which he sealed to suffocate him, the deeply grieving Isis sailed around the kingdom in search of him. When she finally found his coffin,

The Great Goddess placed her face against the face of Osiris, embraced his body, and wept with grief. Then she placed the wings of a bird upon her arms and hovered over Osiris, flapping her wings in order to create air for him to breathe ... 
Finally, she skillfully uttered the magical words of power in a way that she knew would bring temporary life to Osiris ... With delight, Isis embraced her great love and enjoyed him for as long as she could. Then, when Osiris once again lay lifeless and still, Isis replaced his body in the box. (Rosenberg I8)

Impregnated, Isis gives birth to Horus, whom she secretly raises on an island in the swamps of the Nile delta. Later, when Osiris's angry brother, Seth, happens upon the hidden box containing Osiris's corpse, he dismembers the body and scatters its parts around the kingdom. Isis then sails up and down the Nile in a papyrus boat, weeping and searching for the pieces of her love in the hope of attaining justice - hence her quintessential association with boats, water, grief, fragmentation, and vindication. When she finally gathers all the pieces, she reassembles him and wraps him with ointment and spices. She and Horus then travel to the underworld, where the goddess pronounces an incantation that returns Osiris to life.

The festivals of Isis re-enacted the weeping woman parading through the town in grief, and were a precursor for celebrations such as the Passion of the Christ. Thus, as Benko explains:

As wife she could be looked upon as a prototype of earthly relationships and as mother she was often depicted in statues holding her infant son in her lap. This theme later developed into Isis lactans, i.e., Isis nursing her son ... Women thus saw Isis as the divine protectress who on a celestial level already experienced everything that a woman can experience in her life cycle; to all her devotees she was the divine image of the female sex, protectress of all female functions. (49)

Accordingly, as Benko documents, "Many women were among the office holders of the cult" (48). Isis was thus a goddess of fertility, the moon, and the cycles of life manifest in humans and crops. The moon seen in so many portrayals of the Virgin Mary was also a pre-Christian symbol of fertility, often represented with Isis and other fertility goddesses (Benko 23-25). Isis is associated with both the heavens and the waters - "for the Egyptians the 'heavens' were also the primordial ocean, the water from which everything came" (Benko 44). She represents both the origin of life and the comforter to the dead.

With the repetition of Catholic discourse and imagery, Ortiz's stories problematize discursive processes by which the Spanish have subsumed African otherness into the self. Isis figures as a foundational referent that repeats symbolically in Ortiz's tales and cuts into the Catholic discourse. For the villagers of "Fátima de los naufragios," the statuesque, dark- 
skinned, mourning woman staring out to sea in search of her lost one embodies their deepest angst and protects them from further harm. Despite the woman's darker skin, they ignore the African origins that undergird this figure; whether they do so intentionally, obliviously or indifferently is not clear in the text. Just as with the madona morena, they strive to incorporate her otherness as a reflection of their own identity. As Cornejo-Parriego assesses: "Todo ello apunta a la construcción de un ícono híbrido y sincrético en el que el mestizaje es a la vez cultural, estético, religioso y racial" ("Espacios híbridos" 524). Linhard reminds us that the story also can be seen to "reveal the limits of a desired hybridity ... Hybridity instead should not be taken for granted as a happy ending for any story of migration, but rather as the beginning of an interrogation of subjectivity in the first place" (42I). The repetition of the discourse of $l a$ moreneta in the text unveils a fundamental layer in the palimpsest of hybridity: the skin of the supposed virgen morena is also an emblem of Isis, goddess of the water associated with boats, with travel, with searching and finding, with healing and devotion and justice. The alternative goddess evoked by the immigrant woman underscores the injustice of the immigrant plight.

Importantly, the African woman as a repetition of Isis also questions the Catholic repression of sexual love in favor of motherly love. Some of the villagers in "Fátima de los naufragios" perceive an unsettling undercurrent of sensuality in their newly minted Madonna and child, when the body of a young black man is washed up on the beach and the woman embraces it, weeping with joy:

[A]llí permanecía la mujer crecida sobre la arena, hecha Piedad que sostenía el cuerpo bruno del muchacho sobre sus sólidas piernas abiertas como cuna y con sus manos limpiaba la sal y quitaba las algas prendidas del cabello. Un cuerpo de hombre joven medio desnudo, miguelangelesco y bien torneado que recibía los primeros rayos del sol y resultaba hermoso, desplomado sobre las rodillas de la madre. El Antonio, desde lejos, movió la cabeza y dijo: “Ése no es su hijo. El Mohamed contó que tendría unos nueve años y ése es un mozo hecho y derecho. El marido tal vez." (19)

The sight of the woman embracing the beautiful body of the young man, evoking Michelangelo's Pietá, causes consternation for the Spaniards: does she hold and weep for her husband or her son?

This Pietá scene of the woman enveloping the male body with her own conjures MacKendrick's image of the fold as a figure of ethical language. If touch evokes a repeated pattern, MacKendrick argues, then the fold 
embodies repetition multiplied: "Folding draws surfaces and portions of surface together without their ever quite fusing, though they may be brought into contact, brought to the point of touching ... Moving from touch to fold we move from brushing across the surface to wrapping around it, from touching upon the possibility of meaning to folding around the space where meaning would be" (93). The young African man in "Fátima de los naufragios" is a repetition, another dark-skinned immigrant body capsized, yet her body embracing his enfolds vast complexity that spawns more questions in terms of his possible relationship to her, his country of origin (he may be from farther south because his skin is darker than hers, the villagers observe), and the extent of the globalization - in which Spain plays a part - that brings its wreckage back to Spanish shores. The possibility of sensual love that unsettles the villagers who observe the scene is precluded from the canonical discourse of the Virgin Mary, but it recalls the search of Isis for Osiris, a reunion that culminates in copulation. ${ }^{8}$ Throughout the tale the repeated imagery of the immigrant African woman on the beach enfolds associations with the African goddess of love, fertility, and water, iconized in her boat that searches for justice and what was lost.

I suggest that Ortiz's layered folds of discourse in the Pietá image goes even further, through the interplay of both stories, to critique the viability of the hymen as an impenetrable border maintained to contain women in any culture. For "La piel de Marcelinda" conjures a similar Pietá scene when the prostitute gathers Chano's dying body in her arms: "Y él agarrado a la mano de la Marcelinda, que parecía una Magdalena, allí acostada sobre él, empapada en su sangre..." (40). The girl's subsequent thrusting of his knife into her own body constitutes a literal cut that ruptures the status quo of power, as well as a figurative cut in the dominant discourse, which creates space for the other as subject. Though far from an idealized empowerment, the phallic knife penetrates the girl's body of her own choosing, in a desperate act of agency to deliver herself from sexual objectification. Ortiz's allusions to active female sexuality in the non-Virgin depictions of femininity in these tales bear an interesting parallel to the Islamic view of women as sexually active beings that require spatial containment, as Moroccan sociologist Fatema Mernissi discusses in Beyond the Veil. Christian and Islamic societies hold opposing assumptions of women's active role in sexuality, Mernissi asserts, yet share a common outcome of restricting women - through body image in Christian cultures, and through spatial containment in Muslim cultures. If the Virgin is the ultimate representation of static, passive, idealized body image, in Ortiz's immigrant-turned-madona morena there also throbs the threat of active 
sexuality and subjectivity, which is constricted on the borderland of the beach or of death. Thus, whereas Ortiz's first tale highlights the hegemonic interests that project a virginal identity for women and hints at the sexuality pulsating beneath the surface, her second story further explores and underscores the injustice of the whore identity housed on the other side of the hymen.

If the suicide scene in "La piel de Marcelinda" figures enfolding that complicates the effort to incorporate the immigrant in the pious Pietá imagery, the narrative discourse of the suicide scene in "Fátima de los naufragios" enacts repeated touching that reveals a similar failure to subsume the Africans within a Spanish self-image. The Spaniards in "Fátima de los naufragios" ultimately accept the female African immigrant ensconced on their beach, to the point where they enshrine her memory there through a repeated ritual even after she walks into the sea. After the woman weeps over the male body that she has recovered, she invests the Spaniards' mantle with her own meaning by laying it over his body and then walking into the water. Her disappearance is an act of suicide that the Spaniards revere as some sort of virginal Ascension - it is a miracle that brings an absence more easily hallowed than her presence. In their view, she assuages their guilt, embodies their grief, and mourns their losses. They immobilize her as a repeated icon of white religion that positions woman as a loving, forgiving mother whose hymen embodies a sacred membrane of inviolate stasis and passivity. In its move toward ethical representation of the other, the discourse used to narrate this climactic beach scene enacts repetition. MacKendrick asserts that "repetition consequent upon and intertwined with incompletion, is characteristic too of the sense of touch. To touch (I shall say it again) is not to grasp; the knowledge given us by touch is always partial, and passes over, and returns. It always leaves more to be desired" (52). The narration of the scene posits imagery, syntax, and meaning that embody repetition, not grasping: "Y se hizo un silencio de misa de domingo, y la mora cubría el cuerpo del hijo con el manto de franjas rojas y moradas, y solo se escuchaba el sonido del mar, un aleteo rítmico del ir y venir de las olas que convertía a la playa en cathedral..." (20-2I). The very beginning of the sentence and its internal dependent clauses with the word "And" enacts a repetition that at once reverberates like a religious litany and effectuates the motion of syntactic touching, a repeated stroking that never grasps hold of its object. As MacKendrick observes, to create the repetitive touching of language, "rhythm, repeating patterns of temporality, is important" (53). Ortiz's linguistic stroking also evokes repetitive sound 
through the image of rhythmic waves that create the effect of music reverberating in a cathedral.

Notably, the focalizing Spaniards perceive the space of nature in this climactic scene as a repetition of the site of religion, as if the latter were the origin of meaning and reference. The Spanish women raise their voices in prayer, with their intoned utterances melding with the rhythmic waves: "Y el rezo de las mujeres se unió al bramido terco del mar y sobre el cuerpo del muchacho, que yacía en tierra, una gaviota blanca y negra volaba hacienda círculos, paloma marina..." (2I). However, in tension with the Spanish villagers' perception of this scene as a Catholic tableau, there hovers, for readers to perceive, an alternative interpretation of science and nature as the source of meaning: there is dead flesh on the beach, hence the seagull - rather than a seaside dove whose circular flight symbolizes spiritual unity and favor - is a natural predator that circles overhead in anticipation of carrion to eat. Thus the narrative strategy of signification evokes another repetition that harbors alterity, to subvert totalization. The Spaniards strive to incorporate the African through their religious discourse, yet the narrative strategies render their perception as a failed effort that falls short and draws near again, in a tactile enactment of approach and retreat to and from the immigrant woman, who eludes their grasp.

It is interesting to note that the pulsing pattern of linguistic phrasing in both stories creates an oscillating effect of approach and retreat, in and out, that echoes the sexual desire that is problematized in both tales. The entire speech pattern of the narrator of "La piel de Marcelinda" is characterized by a string of phrases connected together, many beginning with "que" and " $y$ " to continually heap on more information in an eternally repetitive, syntactic motion that postpones completion as it builds in intensity. The textual and sexual pulsing crescendo in the final scene of "La piel de Marcelinda" when Chano fights off the four drunk and violent Spanish men who want to have their way with Marcelinda all at once:

Y entonces corro para ayudar al chaval, mientras la Marcelinda y la Morosca comienzan a dar gritos y el jeta de los rizos, un hijoputa que venía a lo que venía, saca antes de que yo pueda guiparle, enfrascado como estaba con el de la chupa, y entonces veo el brillo, como un destello, todo rápido y luego oigo el alarido del Chano y me vuelvo hacia él, y los otros cuatro que salen corriendo y se meten en el coche y aceleran. Y allí queda el Chano. (40)

The textual rhythm of "y ... y ... y ..." effectuates the rhythm of sexual desire that climaxes, not with orgasm, but with death from the thrusting of a 
knife. Yet this petit mort is not the end of the Spanish desire to approach the other, and, accordingly, the narrator's repetitive phrasing pattern continues: "la Marcelinda desangrándose sobre el Chano, que tenía los ojos muy abiertos ... y allí los cuerpos, el cuerpo tan negro con esos ricitos de colores y la mancha de la sangre, tío, y los ojos abiertos del Chano, que tenía una mirada que no sé si era de estupor o de felicidad, que me daba escalofríos, y..." (4I). As the narrator recounts the killing of Chano and the suicide of Marcelinda, his phrases pulse and quiver with aftershocks at what he has witnessed. Hence the repetitive syntax also creates the effect of the story rushing out in a torrent, unstructured and overflowing from the narrator's agitated mind - his uncontrolled release. Similar to "Fátima de los naufragios," in "La piel de Marcelinda" Ortiz emphasizes the strategy of linguistic repetition in the culminating scene to represent the effort to draw near to and comprehend the death of the other as a desire that is never completed or realized. In this ever-approaching, never-attaining structure of language, the other is not to be grasped.

If the Pietá and suicide scenes in these stories play out ethical strategies of repetitive touching and enfolding in their treatment of the other, their focalization technique may be seen as a dramatization of both touching and the cut. Focalization is a primary vehicle of repetition and rupture through which the stories depict the Spanish gaze as a quintessential tool of power over the African other, and unveil the illusion of its comprehensive view. In "Fátima de los naufragios" various characters present their point of view, and virtually all are Spaniards, mentioned by name and/or trade - "Antonio el pescador" (8), "Lucas, el hijo de Antonio" (9), "Felisa la panadera" (9), "Paquito, el hijo de la Toña" (Io), "la Encarna" (II), "el Constantino, hombre de mucho navegar" (I5), "la mujer del cartero" (I7). The villagers' observations seem to comprise a collective Spanish perspective that perceives the woman as alien at first, then gradually incorporates her into their worldview through religious discourse, as discussed above. The notable exception to the predominant Spanish focalization is when the villagers urge the immigrant Maghrebi boy, Mohammed, who was on the capsized boat with the Moroccan woman, to go talk with her and bring them back information. Yet even Mohammed's focalization, wherein he describes his observations of the woman, is subjugated to the focalizing view of the Spanish villagers, who watch his new encounter with her from afar, then hear his account and comment on it. ${ }^{9}$ Markedly absent from the repeated parade of focalizers is the African woman herself, the object of the narrative. Readers never see her perspective nor hear her words directly, only the viewpoint of those who watch her gazing at the sea. The absence of her focalization reveals 
the blindspot that ruptures the supposed panorama of perspectives proffered by the story.

"La piel de Marcelinda" similarly employs focalization through Spanish eyes, but with the probable effect of alienating many readers because of the crass, overtly sexual objectification that characterizes the dominant gaze. The story is narrated in the first person by one of the establishment's guards, who is also the sole focalizer, though he reports on the way other Spaniards look at the prostitutes. Hence the story forces readers to see the women's bodies through his gaze: "daba gloria verlas con aquellas piernas como troncos, duras, perfectas y esas bocas con unos dientes tan blancos y una delantera imponente de agárrate para no caer. Empinaditas y bien puestas, como debe ser, que a los clientes se les hacía la boca agua con solo mirarlas" (26). He justifies their sexual exploitation - "Que no es mala vida, si nos ponemos a ello, ni para ellas, ni para nosotros. Un poco chungo a veces, porque hay que pasarse allí las horas muertas y hay mañanas que dan pena de aburrimiento" (28), and he later adds "[q]ue además les gusta" (33) - and watches them work from his vantage point lounging beneath a tree (29). Certainly readers can imagine that the "boring" hours of no penetration would be the least of the women's concerns. Toward the end of the story even the narrator admits that Marcelinda seemed not to like her job: "que la verdad es que no creo que la cosa le iba ni un poquito y que lo pasaba fatal cada vez que, pero ipuñetas! El mundo es como es y seguramente en su tierra estaba buscando comida en las basuras, que eso me lo ha contado el Goyito, que sabe muy bien de dónde las saca, así que agradecida debería estar" (38). By forcing readers to see through the narrator's gaze and listen to his repeated justifications of the sexual selling of the immigrant women, the story seeks to effect a rupture, a disassociation of readers from perceiving this exploitation as acceptable.

Just as these stories unveil how the Spanish gaze approaches the immigrant other, only to retreat and repeat its effort to possess, the texts strive toward an ethical representation of the immigrant women's voice and perspective, even through their absence. In "Fátima de los naufragios" the African woman's voice is notably missing, as is her focalization. MacKendrick envisions such a lack of the other's articulation as a paradoxically ethical disruption of discourse: "[I]n this breakage and disruption we find certain positive possibilities of language, of conversation rather than monologue. Where one self breaks off its flow of words, there is room for another, who in some sense may well be the source of those words' very possibility, the reason for our speaking and writing" (I42). Rather than speaking for the other, then, the narrative discourse of the tale may be seen to leave room for the other. 
Whereas "Fátima de los naufragios" wields a dynamics of silence in its third-person narration that prods readers to create her a space of ethical integrity, "La piel de Marcelinda" features a first-person narration with abundant citations of Spaniards and even the immigrant women, in order to elicit readers' ethical condemnation of the women's objectification. The immigrant women's voices are heard only through the filter of the focalizing narrator, who indirectly describes their conversations in their native language as "su maldita lengua" (37) or "su endemoniada lengua" (29). The few times the prostitutes' words are represented with direct discourse, the narrator notes their broken phrases and mis-pronunciation: "[E]lla dijo chapurreando que se llamaba Marcey o algo así y el Chano dijo: 'Marcelinda, que es un nombre que te va de chipén.' Así que con Marcelinda se quedó, y era gracioso oírselo llamar a la Morosca o a las otras con su media lengua: 'Meircilinda"' (32). On the other hand, the story proffers direct citations of the Spaniards that unveil the oppressive power dynamics inherent in their sexual and verbal subjugation of the other. At various points the narrator quotes the pimp, Goyito, the other guard, Chano, or, as in this passage, the johns:

...que hay muchos que los pone a cien llamarlas negras y decirles que se vayan pa' su tierra, tratarlas como esclavas, que eso forma parte de la cuestión, como el que va de travestis, ya sabes: primero el insulto y la humillación y luego de señorones: "Que tú me la chupas, que tú eres un mierda." Pues lo mismo con las de color, que los atraen y los excitan, precisamente porque, bueno, les da asco y se creen por encima... (38)

The narrator pragmatically acknowledges the linkage between verbal and sexual abuse in the power dynamics of otherness and desire, especially when that otherness is multiplied by nationality, race, and sexual identity. Such direct citation of the Spaniards, as well as the narrator's attempt to erase the immigrant women by denigrating their words, creates a distancing effect on the level of the text that provokes critical questioning and what Ross Chambers would term "oppositionality" on the part of readers. Rather than familiarly identifying with this narrator, as invited by the narrator's constant references to "tú," the story incites readers to desire differently, to open a gap in the communication process and identify against the speaking subject. . $^{\text {IO }}$ Through these spaces opened up in the text, Ortiz's narratives rupture the dominion of the depicted Spaniards' voice and vision.

In both of Ortiz's tales, notably, the only way out of the repressive bind of cultural and sexual control for the dark-skinned female immigrant is 
suicide. The two stories repeat the image of immigrant death and dwell on its impact on the Spanish spectator. In contrast to the pious assimilation of the African immigrant as Christian Virgin in the first tale, however, the final lines of "La piel de Marcelinda" emphasize the fearful reaction of the Spanish male gaze at what the subversive, dark, female body may represent. The narrator concludes his tale with the image of the dead Marcelinda's skin that haunts him: "Que desde aquel día se me congela la saliva y apenas duermo. Era una piel marrón como de cera, de museo de terror, una muñeca disecada con los ojos de cristal, como esos alfileres de los acericos. ¡Había que verla!” (42). As throughout the story, the narrator positions readers again as Spanish accomplices in his view, this time by assuming their shared cultural knowledge of the little pins with crystal heads that everybody's mother had in twentieth-century Spain. These crystal pinheads now occupy the space of Marcelinda's eyes, protruding from her body, which has transmuted from wax statue to dried-up doll. That is, beneath the consecrated authority of the Christian Virgin lurks the menacing power of an African voodoo doll. The masculine, Spanish gaze sees in this specter of otherness an object of horror - the specter of African culture that might endure despite the cultural displacement and layering caused by colonialism, slavery, and globalization. The transformation from immigrant to whore to virgin to voodoo doll dramatizes the unsettling artificiality of the borders erected by the phallocentric gaze and the anxiety produced when comfortably opposed binaries of difference are unveiled as one disturbing syncretic identity, which interrogates the perceived foundations of identity. This fear-ridden confrontation of the hegemonic gaze with the specter of otherness is waged upon the woman's body, a terrain of boundaries crossed: Spain/Africa, virgin/whore, Christian/nonChristian and, undergirding all these binaries, powerful/powerless. The skin of the dead girl is, significantly, dried out; it has become a parchment, where the male Spanish narrator inscribes what for him is the horror story of dark-skinned female resistance to European, colonial, phallocentric power. Readers are left to choose to comply with this vision of the female immigrant or oppositionally critique it and alter the course of her story in Spain.

Lourdes Ortiz's texts unveil ways in which Spaniards attempt to grasp the immigrant other: they draw near, then distance themselves, then approach again. This oscillation enacts an attraction and repulsion to the other that alienates and also approximates in an effort to grasp and incorporate her within the self. Yet on the narrative level, the repetitive touching of language, which begins as soothing as a litany, does not grasp the African woman into Spanish identity but rather repeats inexorably to 
rub the parchment raw - revealing the folds, cuts, and ruptures of the skin where these two cultures come in contact. In these breaks we see the intersectional conflicts of race, gender, nationality, and class festering on and beyond the surface of the skin. Rather than repeating the cultural custom of viewing the skin as commodity and consuming the immigrant body with a Eurocentric gaze, however, Ortiz exposes the surface of the skin as a sheath of identity politics in Spain. In so doing, her fiction inscribes a poetics of skin in a tactile, ethical approach to the Spanish representation of the African otherness within.

Virginia Tech

NOTES

I McClintock's Imperial Leather: Race, Gender and Sexuality in the Colonial Contest offers an intriguing analysis of the historical role of the female body in imagery of European conquest. Grieve traces this phenomenon in Peninsular narratives of national identity in The Eve of Spain: Myths of Origins in the History of Christian, Muslim, and Jewish Conflict. As a starting point for critical analyses of the contemporary impact of immigration and its portrayal in literature and criticism, readers might consult Andrés-Suárez, Kunz and D’Ors's La inmigración en la literatura española contemporánea; CornejoParriego's Memoria colonial e inmigración: la negritud en la España posfranquista; Flesler's The Return of the Moor: Spanish Responses to Contemporary Moroccan Immigration; Folkart's Liminal Fiction at the Edge of the Millennium: The Ends of Spanish Identity; Martin-Márquez's Disorientations: Spanish Colonialism in Africa and the Performance of Identity; Richardson's Postmodern Paletos: Immigration, Democracy, and Globalization in Spanish Narrative and Film, 1950-2000; Rueda's El retorno/El reencuentro: La inmigración en la literatura hispano-marroquí; and Ugarte's Africans in Europe: The Culture of Exile and Emigration from Equatorial Guinea to Spain.

2 For illuminating analyses of cultural perceptions of skin, in addition to those directly cited in this essay, see Cavanagh, Failler, and Hurst's Skin, Culture, and Psychoanalysis; Connor's The Book of Skin; Fouz-Hernández's Mysterious Skin: Male Bodies in Contemporary Cinema; Jablonski's Living Color: The Biological and Social Meaning of Skin Color and Skin: A Natural History; and Sullivan's Living across and through Skins.

3 In Liminal Fiction at the Edge of the Millennium: The Ends of Spanish Identity Folkart analyzes the cultural prejudices against immigrants that are embodied in the hymen and the anus in Najat El Hachmi's novel L'últim patriarca. 
$4 \quad$ González del Pozo critiques this imposition of the dominant Spanish view as the overarching message and fatal flaw of the story (93-94); nonetheless, I would argue that this predominant viewpoint takes place at the level of the narration and as such does not constitute the message but merely one more technique to be interpreted by readers, who are to choose whether to identify with or critique the discursive dominance imposed by the hegemonic Spanish view. The present essay seeks to demonstrate how, through the complex interplay of narrative techniques, this story problematizes the identity of Spanishness and the objectification of the immigrant in order to unveil and undermine the traditional stereotype of the Spaniard as a singular subject and Spain as a uniform nation.

5 My analysis builds on DiFrancesco's foundational study of the iconography of the Virgin in these texts. DiFrancesco and Leone provide an astute discussion of the discursive interpellation of naming, as the Spaniards christen the immigrant women in both tales.

6 Benko compares the biblical image of the woman clothed in the sun with popular images of divine female figures, including the constellation Virgo (meaning Virgin), Isis, and Juno (IIO-I2). He documents the "popular piety around the second century A.D., at which time the great fertility goddesses from Syria to Libia and Rome were considered to be 'the same.' They were all viewed as images of the Virgo, a celestial divinity who was also the mother of the gods ... The concept of the constellation Virgo was destined to play an unusual role in Christian theology just about [this] time ... it was in the interpretation of [Virgil's] Fourth Eclogue that Christians openly identified Mary with the celestial virgin goddess of paganism" (II4).

7 For a starting point on the pre-Christian and African influence on Mariolatry, readers may consult Anta Diop, Ben-Jochannan, Begg, Benko, Bernal,

Birnbaum, Maunder, and Witt. In contrast, texts such as Ballbè i Boada's study of the black virgins in Spain provide a minority view, rejecting out of hand the notion that any image of the Virgin might have evolved from such influences. See Difrancesco for a discussion of how Mary Magdalene may be seen as a transposition of the Virgin Mary.

9 Unlike the Spaniards, whose focalizing view seeks to define the African woman with precision and certainty, for Mohammed she defies definitive categorization: "Mohamed encogió los hombros, dando a entender que podía ser, pero que él no habría asegurado... que no decía ni que sí ni que no, que de lejos parecía la Fátima, pero de cerca podía no serlo" (I6).

Io For a discussion of how texts can incite oppositional interpretations in readers, see Ross Chambers' Room for Maneuver: Reading (the) Oppositional (in) Narrative. 
WORKS CITED

ANDRÉS-SUÁREZ, IRENE, MARCO KUNZ, AND INÉS D'ORS. La inmigración en la literatura española contemporánea. Madrid: Verbum, 2002.

ANTA D IOP, CHEIKH. The African Origin of Civilization: Myth or Reality. Chicago:

Lawrence Hill Books, I974.

BALLBÈ I BOADA, MIQUEL. Las vírgenes negras y morenas en España. Barcelona:

Terrassa, I99I.

BART Hes, Ro LA D. A Lover's Discourse: Fragments. Trans. Richard Howard. New

York: Hill and Wang, I979.

BEGG, EAN. The Cult of the Black Virgin. London: Arkana, 1985.

Ben-Jochannan, Jose F A.A. African Origins of the Major "Western Religions."

Baltimore: Black Classic Press, I991.

в п ко, S те н н N. The Virgin Goddess: Studies in the Pagan and Christian Roots of

Mariology. New York: E.J. Brill, 1993.

B n th IE N, CLAU DiA. Skin: On the Cultural Border between Self and the World.

Trans. Thomas Dunlap. New York: Columbia UP, 2002.

B E R A L, M A R T IN. Black Athena: The Afroasiatic Roots of Civilization. New York:

Rutgers, 1987.

B I R baum, Lu cia Chiavola. Dark Mother: African Origins and Godmothers. New

York: Authors Choice Press, 200I.

CAVANAGH, SHEILA L., ANGELA FAILLER, AND RACHEL ALPHA JOHNSTON HURST,

EDS. Skin, Culture, and Psychoanalysis. New York: Palgrave Macmillan, 2013.

Ch A m B R S, Ross. Room for Maneuver: Reading (the) Oppositional (in) Narrative.

Chicago: U of Chicago P, r991.

CONNOR, STEVEN. The Book of Skin. Ithaca: Cornell UP, 2004.

CORNEJO-PARRIEGO, ROSALÍA. "Espacios híbridos, iconos mestizos: imaginando la

España global." Letras Peninsulares 15.3 (2002): 515-31.

-. E D. Memoria colonial e inmigración: la negritud en la España posfranquista.

Barcelona: Bellaterra, 2007.

DERRIDA, JACQUES. Dissemination. Trans. Barbara Johnson. Chicago: U of

Chicago P, r98I.

—. "Le toucher: Touch/To Touch Him." Trans. Peggy Kamuf. Paragraph I6.2 (I993):

I22-57.

DifRAnCESco, MARia. "Virgins and Prostitutes: Re-imagining Religious

Iconography in Lourdes Ortiz's 'Fátima de los naufragios' and 'La piel de

Marcelinda.'" Letras Femeninas 34.I (2008): 197-215.

FLESLER, DANiEla. The Return of the Moor: Spanish Responses to Contemporary

Moroccan Immigration. West Lafayette: Purdue UP, 2008.

F OLKA RT, JESSICA A. Liminal Fiction at the Edge of the Millennium: The Ends of

Spanish Identity. Lewisburg: Bucknell UP, 2014. 
F o U Z-He RnÁndez, SAntiago, ed. Mysterious Skin: Male Bodies in Contemporary Cinema. New York: I.B. Tauris, 2009.

GONZÁLEZ DEL POZO, JORGE. "Reiteraciones de la otredad: España ante el espejo de la inmigración en 'Fátima de los naufragios' de Lourdes Ortiz." Crítica Hispánica 34.2 (2012): 79-10о.

GRIEVE, PATRICIA E. The Eve of Spain: Myths of Origins in the History of Christian, Muslim, and Jewish Conflict. Baltimore: Johns Hopkins UP, 2009.

J A B L O N S KI, N IN A. Living Color: The Biological and Social Meaning of Skin Color. Berkeley: $\mathrm{U}$ of California $\mathrm{P}, \mathbf{2 0} 2$.

—. Skin: A Natural History. Berkeley: U of California P, 2006.

LEONe, maryanne L. “Colonizing Voices and Visions: Lourdes Ortiz's ‘Fátima de los naufragios' and 'La piel de Marcelinda."' Revista Canadiense de Estudios Hispánicos 30.3 (2006): 449-69.

LINHARD, TABEA A LEXA. "Between Hostility and Hospitality: Immigration in Contemporary Spain." MLN I22 (2007): 400-22.

M A C KE N D R IC K, KA R MEN. Word Made Skin: Figuring Language at the Surface of the Flesh. New York: Fordham UP, 2004.

MART IN-M Á RQUEZ, SUSAN. Disorientations: Spanish Colonialism in Africa and the Performance of Identity. New Haven: Yale UP, 2008.

MA Und ER, CHR IS, E D. Origins of the Cult of the Virgin Mary. New York: Burns and Oates, 2008.

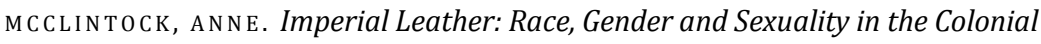
Contest. New York: Routledge, 1995.

merniss i, fatema. Beyond the Veil: Male-Female Dynamics in Modern Muslim Society. Bloomington: Indiana UP, 1987.

oleszkie WiCZ-Peralba, maŁgorzata. The Black Madonna in Latin America and Europe: Tradition and Transformation. Albuquerque: U of New Mexico P, 2007. PÉREZ-SÁNCHEZ, GEMA. "Imaginando historias feministas a ambos lados del Estrecho: Las escritoras españolas se enfrentan al racismo." Escritoras y compromiso: Literatura española e hispanoamericana de los siglos XX y XXI. Eds. Ángeles Encinar and Carmen Valcárcel. Madrid: Visor, 2009. 555-67.

REDFORD, DONALD B., E D. The Oxford Encyclopedia of Ancient Egypt. Vol. 2. Oxford: Oxford UP, 2OOI.

RIC HAR DS ON, NA Th AN E. Postmodern Paletos: Immigration, Democracy, and Globalization in Spanish Narrative and Film, 1950-2000. Lewisburg: Bucknell UP, 2002.

RoS En Be RG, DonnA. World Mythology: An Anthology of the Great Myths and Epics. $3^{\text {rd }}$ ed. Chicago: NTC/Contemporary Publishing Group, I999.

RUED A, ANA. El retorno/El reencuentro: La inmigración en la literatura hispanomarroquí. Madrid/Frankfurt: Iberoamericana/Vervuert, 20 Io. 
SULLIVAN, SHAN N ON. Living across and through Skins: Transactional Bodies, Pragmatism, and Feminism. Bloomington: Indiana UP, $200 \mathrm{I}$.

THURY, EVA M. AND MARGARET K. DEVINNEY. Introduction to Mythology: Contemporary Approaches to World Myths. Instructor's Edition. New York: Oxford UP, 2OI3.

U GARTE, M ICHAEL. Africans in Europe: The Culture of Exile and Emigration from Equatorial Guinea to Spain. Urbana and Chicago: U of Illinois P, 2010.

WI T T, R.E. Isis in the Graeco-Roman World. Ithaca: Cornell UP, I97I. 